\title{
High-Resolution Nonlinear Raman Spectroscopy in Gases
}

\author{
H. W. Schrötter \\ Sektion Physik der Ludwig-Maximilians-Universität München, Schellingstraße 4, \\ $D$-8000 München 40, F. R. Germany
}

and

H. Berger, J. P. Boquillon, B. Lavorel, and G. Millot

Laboratoire S.M.I.L., Université de Bourgogne, 6, bd. Gabriel, F-21100 Dijon, France

Received January 1, 1988

The applicability of Raman spectroscopy to the investigation of gases has been greatly improved by the development of the different methods of nonlinear Raman scattering. When two laser beams, one of which has a tunable frequency, are brought to a common focus in a sample, a stimulated Raman process occurs, as soon as the frequency difference between the two lasers is equal to a Raman active rovibrational or rotational transition frequency of the sample, and the corresponding state is populated above equilibrium. The Raman resonance can be detected in different ways: by coherent anti-Stokes Raman scattering (CARS) or the corresponding Stokes process (CSRS), by a gain in one of the beams (stimulated Raman gain spectroscopy, SRGS) or a loss in the other one (inverse Raman spectroscopy, IRS), or even by detection of a photoacoustic signal (photoacoustic Raman spectroscopy, PARS). The selective ionisation of the excited molecules by a third ultraviolet laser pulse (ionisation detected stimulated Raman scattering, IDSRS) has considerably increased the sensitivity in special cases.

The instrumental resolution of these techniques is determined by the convoluted linewidths of the lasers used for excitation. This is of special importance for the investigation of high resolution rotation-vibrational spectra of gases.

\section{INTRODUCTION}

As long as no lasers with variable frequency were available, only the Raman lines with the highest peak intensity could be observed with the stimulated Raman effect ${ }^{1,2}$ because these alone were sufficiently amplified. The observation of the inverse Raman effect ${ }^{3}$ required a strong continuum source simultaneously with the narrow-band pulsed laser. For the first demonstration of coherent anti-Stokes Raman scattering ${ }^{4}$ the second frequency was generated by stimulated Raman scattering in different liquids.

The development of tunable dye lasers (see ${ }^{5}$ ) made the different techniques of nonlinear or coherent Raman scattering applicable as a powerful 
tool of molecular spectroscopy. In this article we restrict our attention to those techniques which have been used to record high-resolution spectra of molecules in the gas phase.

All these coherent Raman processes are generated when two laser beams, one of which has a tunable frequency, are brought to a common focus in the sample (see Figure 1). As soon as the frequency difference $\omega_{1}-\omega_{2}$ of the two

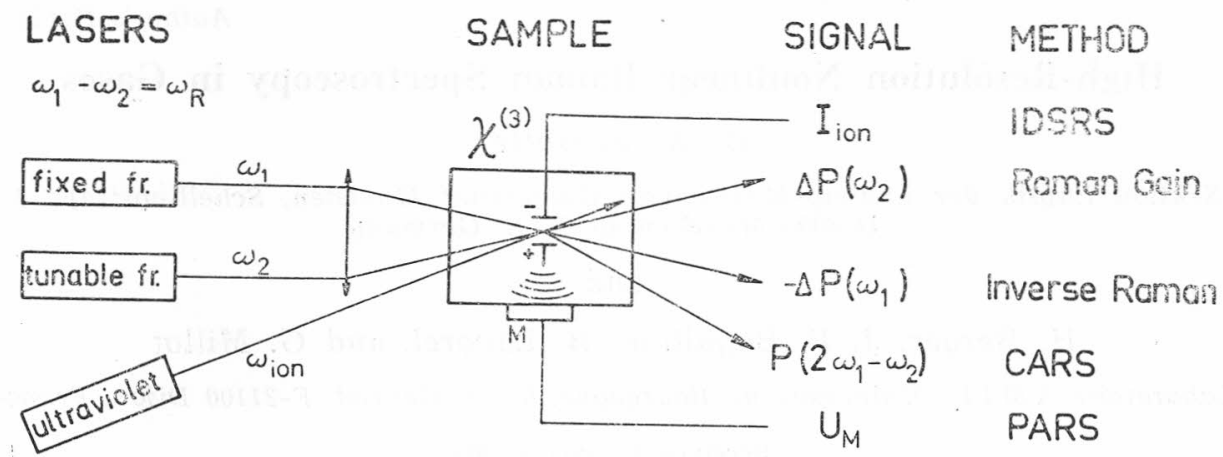

Figure 1. Various nonlinear Raman scattering processes (IM sensitive microphone, $\omega_{\text {ion }}$ ionizing laser frequency).

lasers corresponds to the frequency $\omega_{R}$ of a Raman allowed rovibrational transition, a nonlinear interaction with the molecules occurs via the third order nonlinear susceptibility $\chi^{3}$ (see references 6-11) and the corresponding state is coherently excited. This interaction can be monitored by one of the methods mentioned in the abstract (and summarized in Figure 1) and the spectrum is obtained by scanning the tunable laser.

In this article we want to describe briefly these different techniques of nonlinear Raman spectroscopy and give some examples of their application. More detailed information can be found in previously published books ${ }^{9,12,13}$ and review articles ${ }^{7,11,14,15}$.

\section{STIMULATED RAMAN GAIN SPECTROSCOPY (SRGS) AND INVERSE RAMAN} SPECTROSCOPY (IRS)

Stimulated Raman amplification with tunable lasers has at first been demonstrated in liquids ${ }^{16^{-18}}$. With the help of a multipass optical cell high enough sensitivity was achieved by Owyoung et al. ${ }^{19}$ for nearly Doppler-limited resolution in the spectrum of the $\nu_{1}$ band of methane at a pressure of $4.6 \mathrm{kPa}$ by the c. w. SRGS technique. This work marked a breakthrough of nonlinear Raman spectroscopy to the resolution of the Q-branches of rotation-vibrational bands of polyatomic molecules and their detailed analysis.

The mechanical or electrooptical modulation of c. w. lasers was soon superseded by the use of injection locked pulse amplified pump lasers in combination with quasi- c. w. probe lasers ${ }^{14,20}$. When the probe laser has a higher frequency than the pump laser, one obtains a Raman loss or inverse Raman spectrum, when the probe laser has the lower frequency, a Raman gain spectrum is observed by tuning one of the two lasers. Through the pulse amplification of the pump laser its linewidth is increased over that of a c. w. laser to between 60 and $100 \mathrm{MHz}\left(0.002\right.$ to $\left.0.003 \mathrm{~cm}^{-1}\right)$. Nevertheless, the resolution in 
these experiments is largely determined by Doppler and residual pressure broadening.

Figure 2 shows the experimental setup for high-resolution inverse Raman spectroscopy at the Universite de Bourgogne. The probe laser is a single mode argon ion laser stabilized to a hyperfine component of ${ }^{127} I_{2}$ by saturated $a b-$ sorption spectroscopy. The pump source is a very narrow bandwidth c. w. dye laser amplified by a fourstage dye amplifier pumped by a frequency-doubled Nd:YAG laser and delivers pulses of about 1 MW at a repetition rate of $10 \mathrm{~Hz}$. A Michelson wavemeter operating in vacuum provides measurements of the absolute dye laser frequency with an accuracy of about $2 \mathrm{MHz}^{21}$.

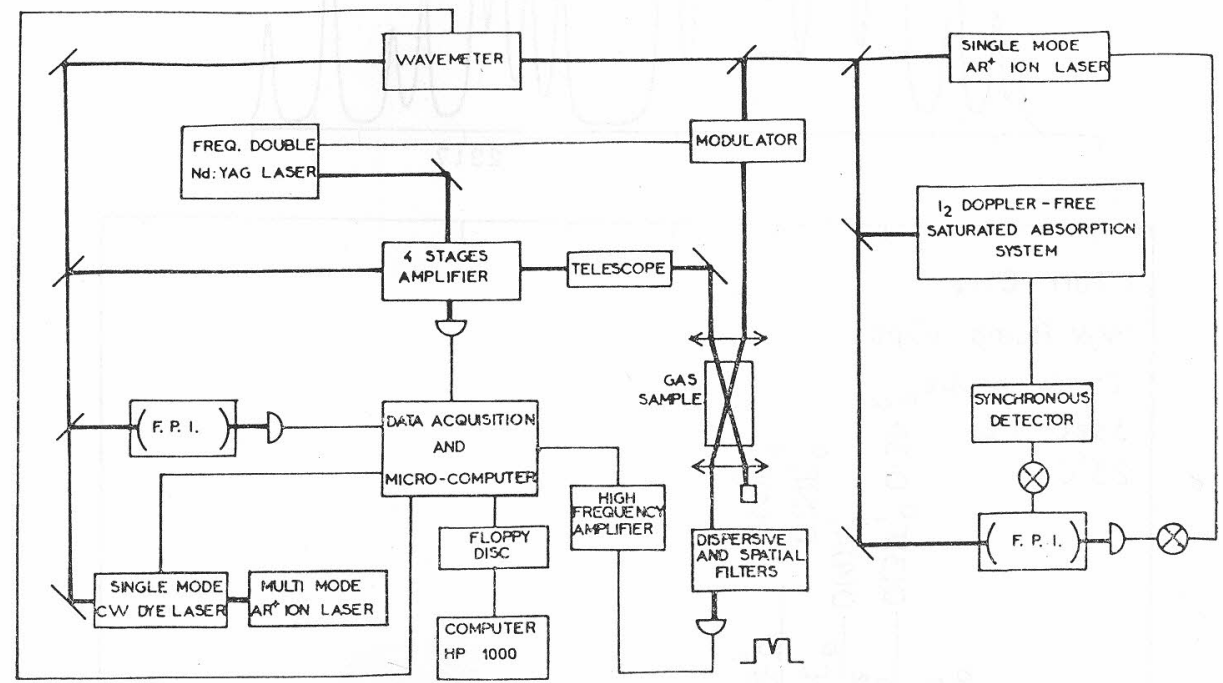

Figure 2. Experimental setup for high resolution inverse Raman spectroscopy (from Millot et al., Ref. 25).

Using the techniques of SRGS or IRS the Q-branches of the $v_{1}$ bands of the spherical top molecules ${ }^{12} \mathrm{CH}_{4}{ }^{19,20},{ }^{13} \mathrm{CH}_{4}{ }^{22},{ }^{12} \mathrm{CD}_{4}{ }^{23,24},{ }^{13} \mathrm{CD}_{4}{ }^{25}, \mathrm{SiH}_{4}{ }^{26,27}$, $\mathrm{GeH}_{4}{ }^{15,28,29}, \mathrm{CF}_{4}{ }^{30}$ and $\mathrm{SF}_{6}{ }^{31}$ have been resolved and analysed. As example we show in Figure 3 a part of the $\nu_{1}$ band of methane ${ }^{12} \mathrm{CH}_{4}{ }^{20}$ The simulated spectrum in the upper part of the figure was calculated by using the energy levels obtained in the course of analysis of the CARS spectrum of the same band $^{32}$, which will be discussed below. A more recent example is the inverse Raman spectrum of the $\nu_{1}$ band of the rarest methane isotope ${ }^{13} \mathrm{CD}_{4}{ }^{25}$ which has been analyzed together with the infrared spectra of this molecule. Figure 4 shows a section of the extended spectrum, in which also contributions from the $2 v_{4}, v_{2}+v_{4}$, and $2 v_{2}$ bands were recorded, and demonstrates the excellent agreement between the experimental (upper) and calculated (lower) spectrum.

The Q-branches of the $\mathrm{CH}$-vibrations of the symmetric top molecules ethane $\mathrm{C}_{2} \mathrm{H}_{6}{ }^{14}$ and cyclopropane $\mathrm{C}_{3} \mathrm{H}_{6}{ }^{33}$ yielded very complicated structures under high resolution. In such cases it is useful to reduce the complexity of the spectra by cooling or by supersonic expansion molecular jets in which the temperature and thus the number of populated rovibrational levels is 

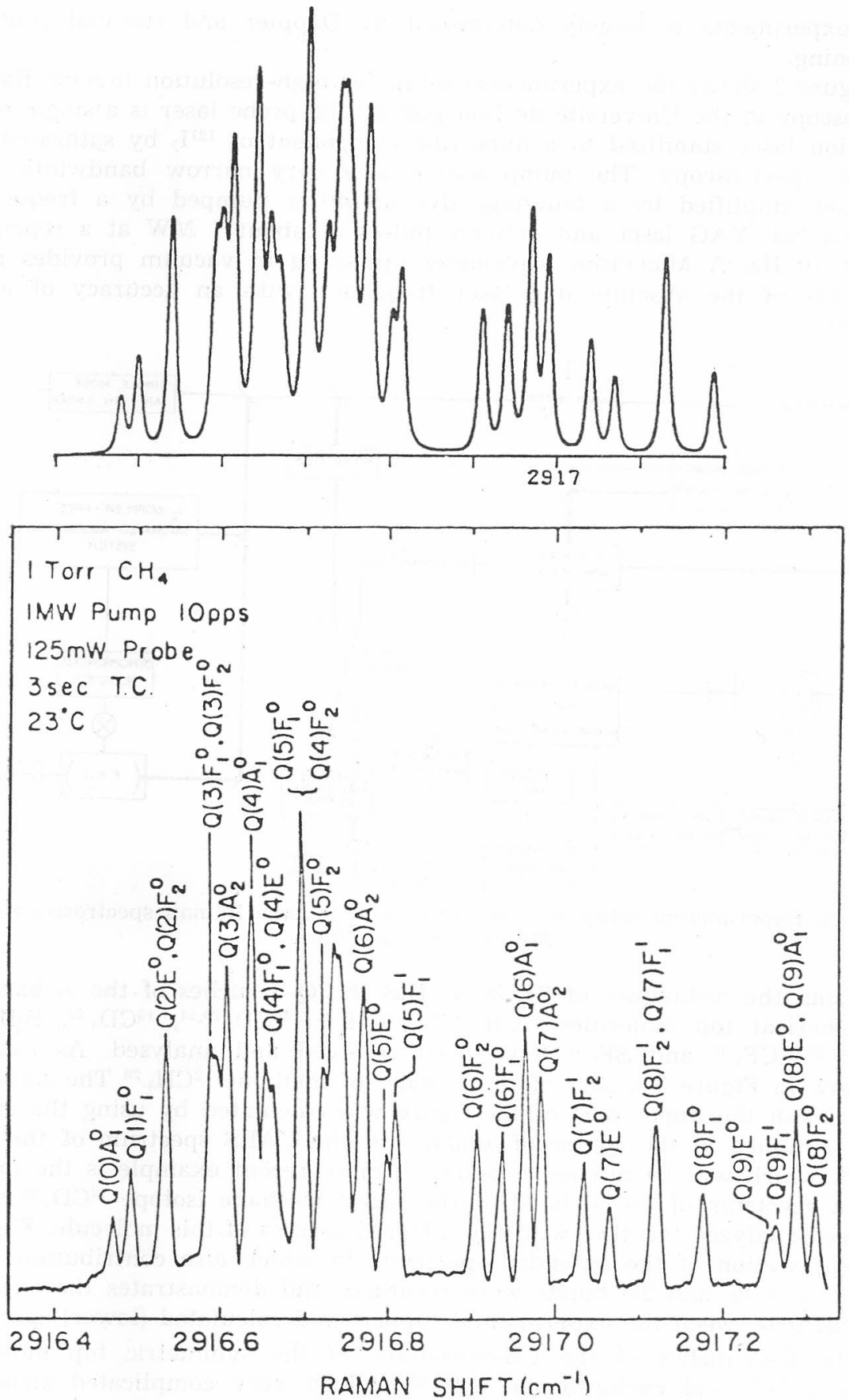

Figure 3. Inverse Raman spectrum of the $\nu_{1}$ band of methane ${ }^{12} \mathrm{CH}_{4}$ at a pressure of $130 \mathrm{~Pa}$. Top: calculated spectrum, Bottom: experimental spectrum (from Owyoung, Ref. 20). 


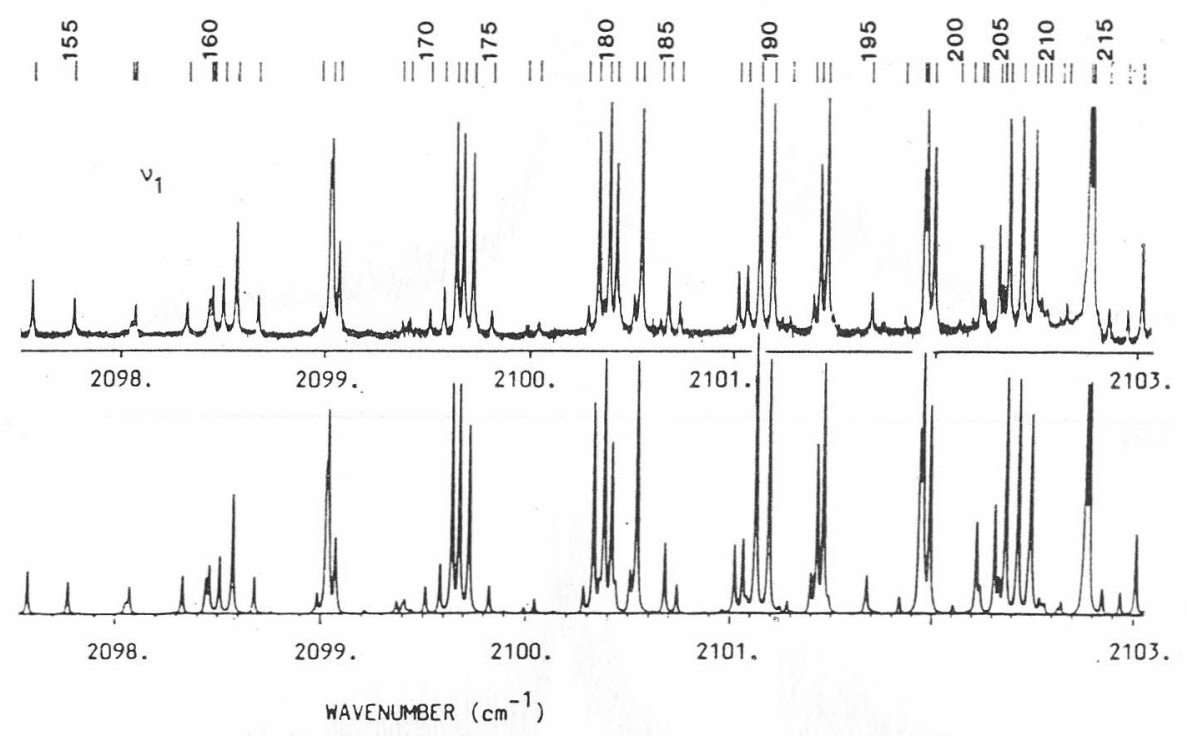

Figure 4. Inverse Raman spectrum of the $v_{1}$ band of methane ${ }^{13} \mathrm{CD}_{4}$ at a pressure of $4 \mathrm{kPa}$. a) Experimental and b) calculated spectrum. Part of the complete pentad spectrum $\left(2 v_{4}, v_{2}+v_{4}, v_{1}, v_{3}, 2_{\gamma}\right)$ trum Millot et al., Ref. 25).

drastically reduced, as had been demonstrated already for methane ${ }^{34}$. Whereas for the prolate top $\mathrm{C}_{2} \mathrm{H}_{6}$ the Raman spectrum was considerably simplified ${ }^{14}$, the effect is less pronounced for the oblate tops because of the many low lying rotational levels due to $\mathrm{K}$-splitting.

Figure 5 shows inverse Raman spectra of the Q-branch of the $\nu_{1}$ band of cyclopropane under different conditions. Reduction of pressure and temperature greatly. improves the resolution, however, also in a molecular beam experiment at an effective temperature of $50 \mathrm{~K}$ the spectrum remained complicated $^{33}$. In addition to the $\nu_{1} \mathrm{Q}$-branch, other bands appear in this spectral range at $3016 \mathrm{~cm}^{-1}, 3018 \mathrm{~cm}^{-1}, 3020 \mathrm{~cm}^{-1}$, and $3036 \mathrm{~cm}^{-1}$, respectively. Vibrational assignments are not easy except for $2 \nu_{2}$ at $3016 \mathrm{~cm}^{-1}$ because many bands fall in this region and can interact with $\nu_{1}$ through Fermi or Coriolis interactions. As a consequence the $\nu_{1}$ band is strongly perturbed and rotational assignments are not possible in the scheme of an isolated band. Starting from a deconvoluted spectrum, Pliva ${ }^{35}$ has arrived at an assignment using an effective Hamiltonian with seven interacting states.

Another interesting application of nonlinear Raman techniques is the measurement of pressure broadening coefficients. Many investigations have concentrated on nitrogen $\mathrm{N}_{2}$ because of its importance for temperature and pressure determination by the CARS technique ${ }^{36}$. The temperature dependence of collisional broadening in $\mathrm{N}_{2}$ had been measured by two groups" independently $^{37,38}$ and agrees so well, that a joint evaluation was possible ${ }^{39}$. The unified data were used to determine the characteristic parameters of fitting laws for rotational transfer rates which are needed to calculate line profiles at high pressure. Both a polynomial energy gap law (P.E.G.L.) ${ }^{40}$ and an exponential energy gap law (E.G.L.) ${ }^{41}$ have been used to fit measurements 

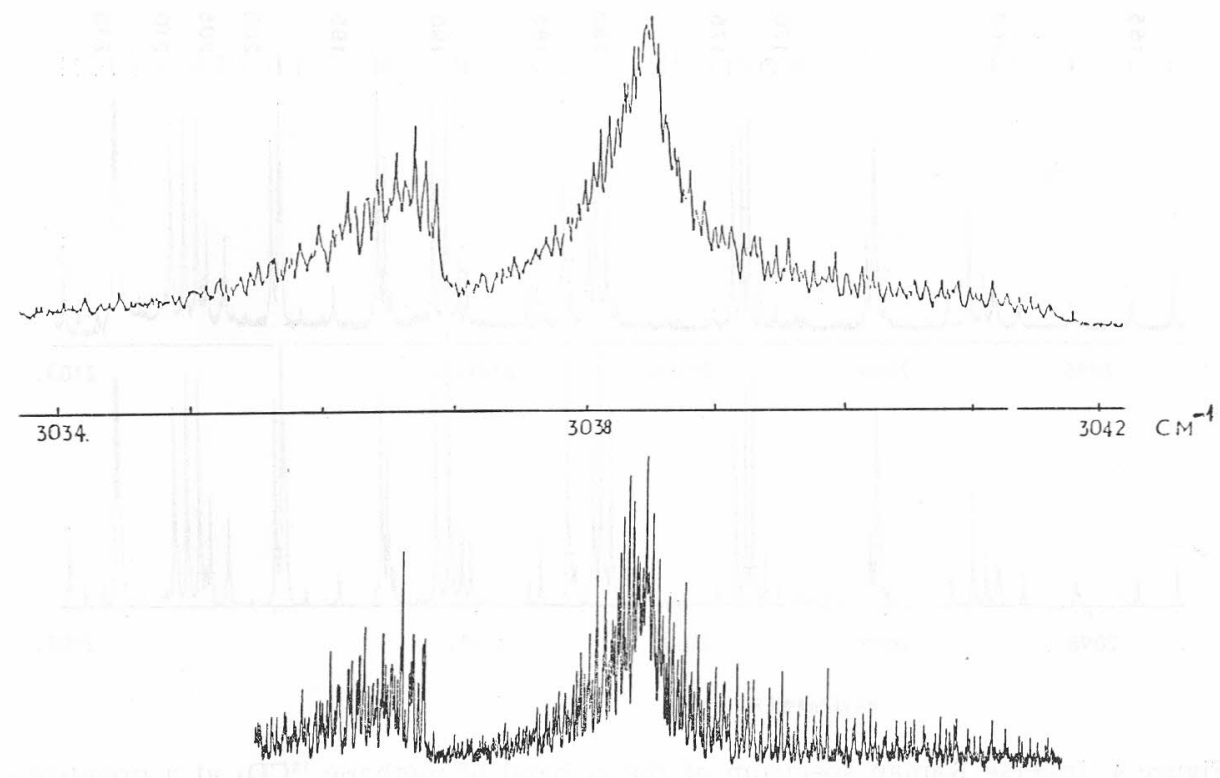

Figure 5. Inverse Raman spectrum of the $v_{1}$ band of cyclopropane $\mathrm{C}_{3} \mathrm{H}_{6}$.

a) pressure $10 \mathrm{kPa}, \mathrm{T}=295 \mathrm{~K}$,

b) pressure $2 \mathrm{kPa}, \mathrm{T}=220 \mathrm{~K}$ (From Terki-Hassaine, Ref. 33).

up to pressures of $3.5 \mathrm{MPa}$. The results are compared in Figure 6 . When the recently and accurately measured pressure shift of the rovibrational frequencies of $\mathrm{N}_{2}{ }^{42}$ is taken into account, the fit with the E.G.L. model is significantly better at room temperature.

\section{COHERENT ANTI-STOKES RAMAN SPECTROSCOPY (CARS)}

The narrowest linewidths and the best resolution can be obtained with continuous lasers. The possibility to excite CARS spectra with c. w. lasers has been demonstrated by Barrett and Begley ${ }^{43}$ and further developments of the technique are due to Hirth and Vollrath ${ }^{44}$, and Fabelinsky et $a l^{45}$.

In order to make the best possible use of the power of a c. w. laser, we have constructed in Munich a CARS spectrometer consisting of a single mode c. w. argon ion ring laser with an intracavity power of over $100 \mathrm{~W}$, a c. w. tunable dye ring laser with a power of 100 to $200 \mathrm{~mW}$, and an intracivity sample cell with focusing spherical mirrors, see Figure $7^{46}$. The CARS signals are detected after appropriate filtering by a photomultiplier connected to a photon-counting system and a dedicated computer for data acquisition. The instrumental resolution is determined by the combined linewidths of the two lasers which amounted to $\simeq 10^{-3} \mathrm{~cm}^{-1}$.

With this spectrometer the CARS spectra of the Q-branches of nitrogen ${ }^{46}$ and the $\nu_{1}$ bands of methane ${ }^{32}$, hydrogen sulfide ${ }^{47}$ and ammonia ${ }^{48}$ have been resolved at pressures between 1.3 and $2 \mathrm{kPa}$, assigned and evaluated. The Q-branch of the $\nu_{3}$ band of methane has also been studied ${ }^{49}$. As an example 

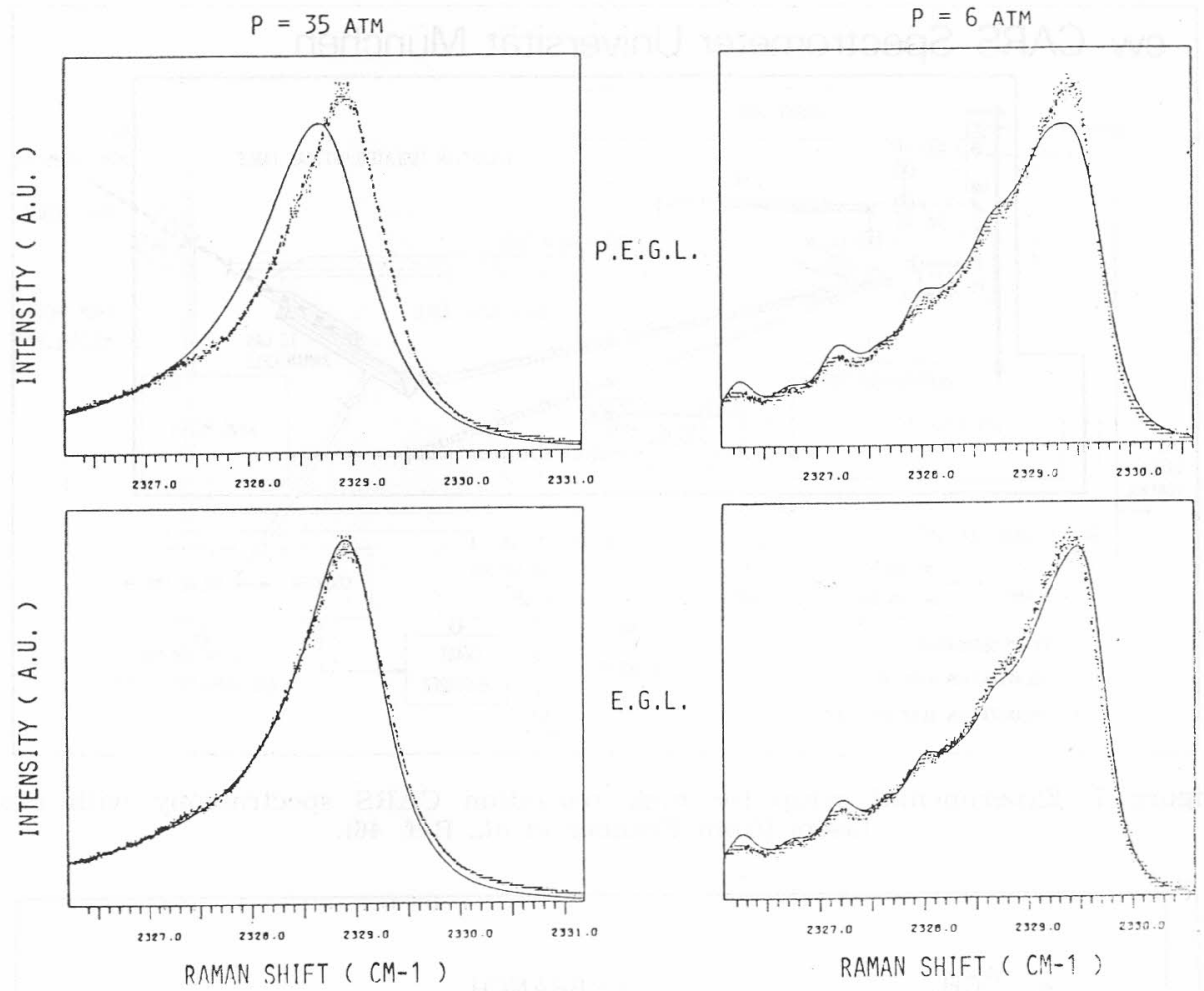

Figure 6. Inverse Raman spectra of the Q-branch of nitrogen $\mathrm{N}_{2}$ at pressures of 3.5 MPa (left) and 0.6 MPa (right). The experimental points are fitted with profiles calculated from the P.E.G.L. (above) and F.G.L. (below) models (from Lavorel et al, Ref. 39).

we show in Figure 8 the CARS spectrum of the $\nu_{1}$ band of methane ${ }^{12} \mathrm{CH}_{4}$ which can be compared with the inverse Raman spectrum of Figure 3 . In the course of the analysis of this spectrum it was found ${ }^{32}$ that about 10 energy levels with angular momentum quantum numbers from $J=6$ to $J=10$ had to be adjusted in an empirical fit in order to reproduce the band profile by computer simulation. Later this was confirmed by Lolck ${ }^{50}$. The wavenumber and linestrength data of the empirical fit have also been used to calculate the upper spectrum in Figure 3.

As an alternative to the c. w. intracavity operation described above high power and narrow linewidth can be obtained by combining the power of pulsed lasers with the spectral qualities of c. w. lasers by injection-locking. If single mode radiation is injected into a pulsed laser cavity the length of which is adjusted to a multiple of the injected wavelength, one can force the pulsed laser to deliver its power on a single longitudinal mode at the same wavelength. The CARS spectrometer in Dijon consists of two flashlamp pumped dye laser amplifiers which are injection-locked to the frequency of stabilized single mode c. w. dye lasers or a krypton and a dye laser. ${ }^{51}$ The amplifiers are operated in a $3 \mathrm{~m}$ long ring cavity with four mirrors. Mode matching is achie- 


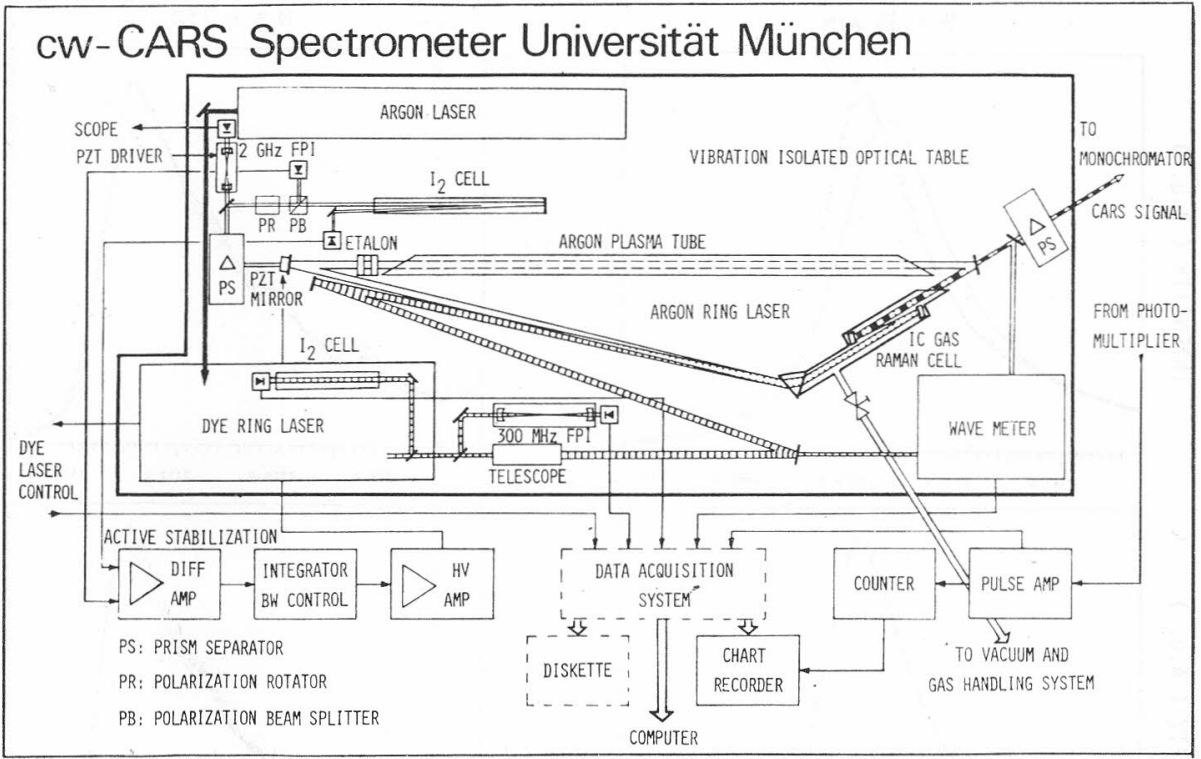

Figure 7. Experimental setup for high resolution CARS spectroscopy with c.w. lasers (from Frunder et al., Ref. 46).

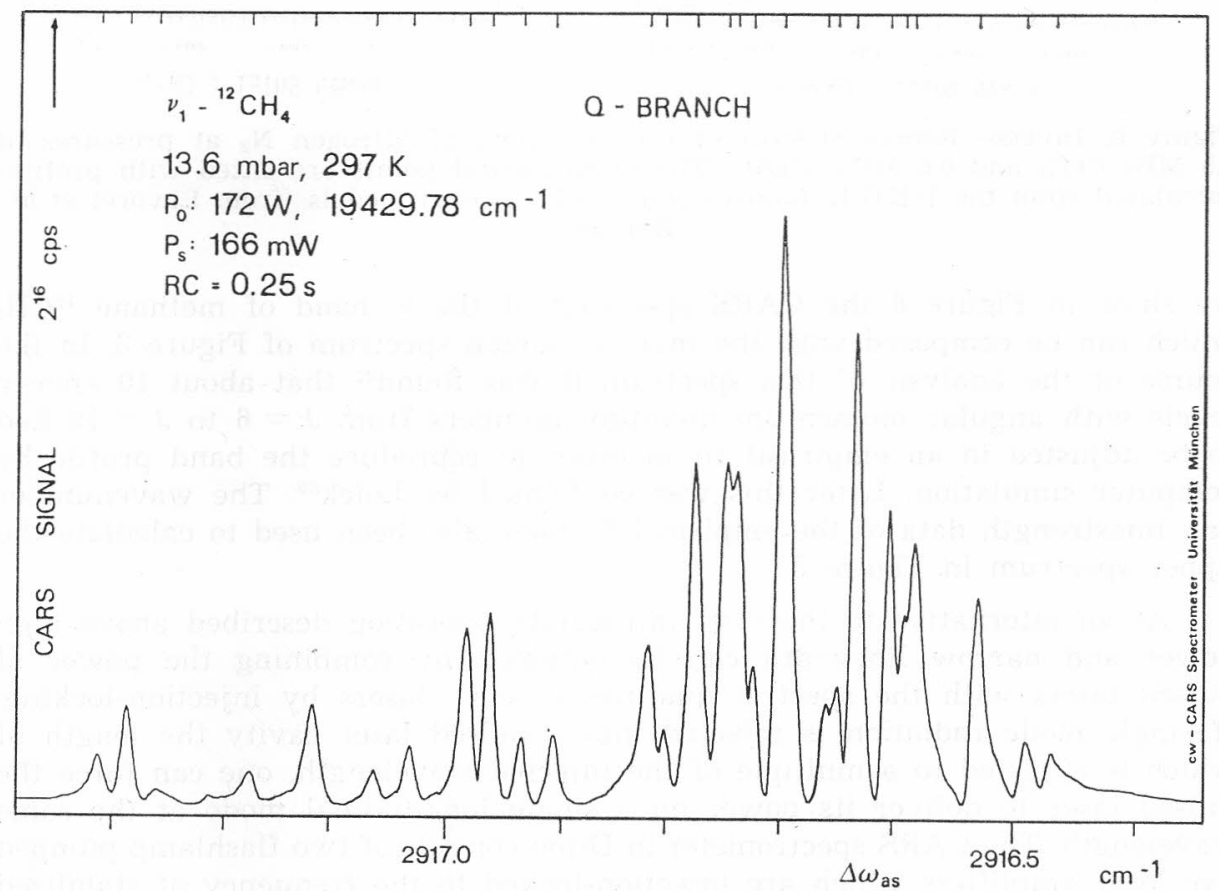

Figure 8. CARS spectrum of the $v_{1}$ band of ${ }^{12} \mathrm{CH}_{4}$ at a pressure of $1.36 \mathrm{kPa}$ (from Frunder et al., Ref. 32). 
ved by adjusting the cavity length through piezoelectric translation of one mirror with an automatic electronic servo-loop, see Figure 9 . The amplifiers deliver pulses of about $300 \mathrm{~ns}$ duration with peak powers up to $12 \mathrm{~kW}$ and a repetition rate of $10 \mathrm{~Hz}$, resulting in a line width of $2.10^{-4} \mathrm{~cm}^{-1}$. The two pulsed beams are sent on a beam splitter which mixes the two beams and sends the resulting two equivalent combinations on separate paths to be focused in two cells of $40 \mathrm{~cm}$ length, one sample cell and one reference cell filled with an inert gas which is non-resonant at the excitation frequencies. After appropriate optical filtering the CARS signals are monitored by two photomultipliers and the ratio is stored in a data acquisition system and averaged over 8 or 16 successive shots. Wavelength calibration is achieved with an iodine absorption cell, a wavemeter ${ }^{21}$ measuring the wavenumber at the start and at the end of each scan, and a confocal Fabry-Perot-interferometer for interpolation.

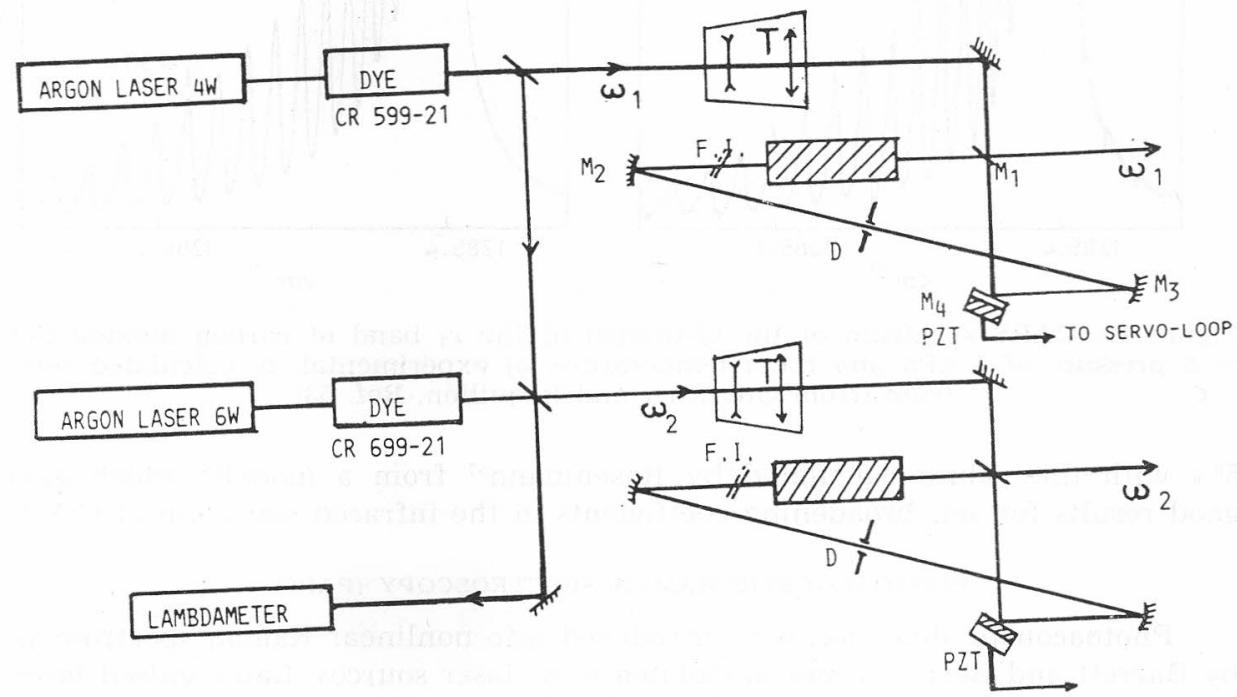

Figure 9. Laser configuration for high resolution CARS spectroscopy with injection-locked flashlamp-pumped dye laser amplifiers. (IM mirrors, T magnifying telescopes, PZT piezo-translators, D diaphragms; from Boquillon et al., Ref. 51).

With this spectrometer the CARS spectra of the Q-branches of oxygen ${ }^{52}$ and of the $\nu_{1}$ band of carbon dioxide have been investigated ${ }^{53,54}$. Oxygen spectra have been recorded at pressures between 1.3 and $130 \mathrm{kPa}$ and by adjustment of the line profiles collisional line broadening coefficients have been determined for the lines with rotational quantum numbers $N=1$ to $N=17$, the values decreasing monotonically from 52 to $38.10^{-3} \mathrm{~cm}^{-1} / \mathrm{atm}$.

For the first time it has been possible to resolve the rotational structure of the Q-branch of the $\nu_{1}$ band of $\mathrm{CO}_{2}$ at about $1285.5 \mathrm{~cm}^{-1}$ at a pressure of 5 $\mathrm{kPa}$ and to assign the lines for angular momentum quantum numbers $J=8$ to $J=38$ as shown in Figure 10. The line positions are in excellent agreement with those calculated from molecular constants given in the literature ${ }^{55,56}$. The collision linewidths have been obtained by a least-squares fitting procedure taking Doppler broadening into account and were found to agree within 

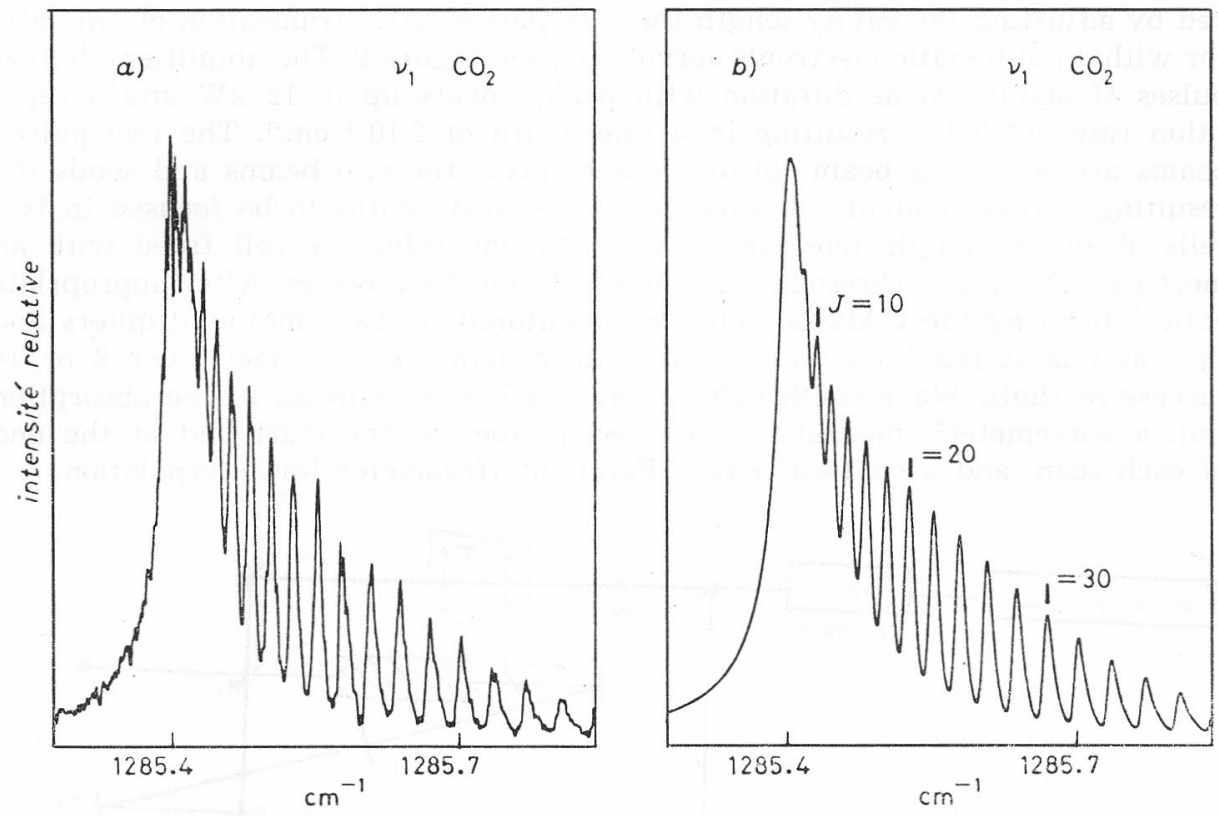

Figure 10. CARS spectrum of the Q-branch of the $\nu_{1}$ band of carbon dioxide $\mathrm{CO}_{2}$ at a pressure of $5 \mathrm{kPa}$ and room temperature. a) experimental, b) calculated spectrum (from Ouazzany and Boquilion, Ref. 53).

$5 \%$ with the values calculated by Rosenmann ${ }^{57}$ from a model ${ }^{58}$ which gave good results for self broadening coefficients in the infrared spectrum of $\mathrm{CO}_{2}^{59}$.*

\section{PHOTOACOUSTIC RAIIAN SPECTROSCOPY (PARS)}

Photoacoustic detection was introduced into nonlinear Raman spectroscopy by Barrett and Berry ${ }^{60}$ using modulated c. w. laser sources. Later pulsed lasers were applied for the excitation of rotational and rovibrational PARS spectra ${ }^{61}$. In this technique the energy deposited in the sample by excitation of e.g. a vibration by the stimulated Raman process leads to a temperature and pressure increase through relaxation to translational energy and can therefore be detected by a sensitive microphone. Figure 11 shows a setup for PARS which uses a frequency-doubled Nd: YAG laser for the pump beam and a dye laser with amplifier pumped by the third harmonic of the Nd: YAG for the Stokes beam ${ }^{61}$. This makes the recording of pure rotational PAR.S spectra possible, a medium resolution spectrum of carbon dioxide is shown in Figure 12. There is no signal at the usual position of the Rayleigh line, because no energy is deposited in the sample. Although it was demonstrated ${ }^{61}$ that the sensitivity of the technique is sufficient to observe Q-branches at pressures below $1 \mathrm{kPa}$, to our knowledge no high resolution PARS spectra have been published so far.

* Note added in proof: In the meantime the same Q-branch has been resolved even better by the technique of SRGS at a pressure of $200 \mathrm{~Pa}$ employing a multiple reflection cell with 50 passes. $^{66}$ 


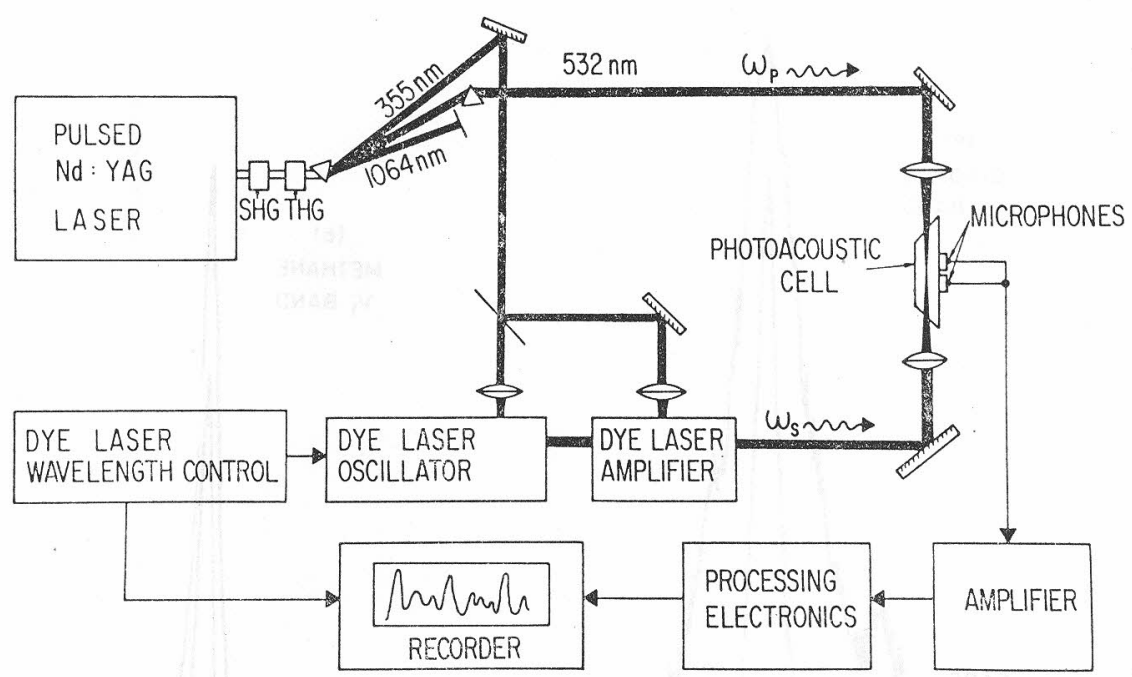

Figure 11. Experimental setup for PARS spectroscopy (from Barrett, Ref. 61).

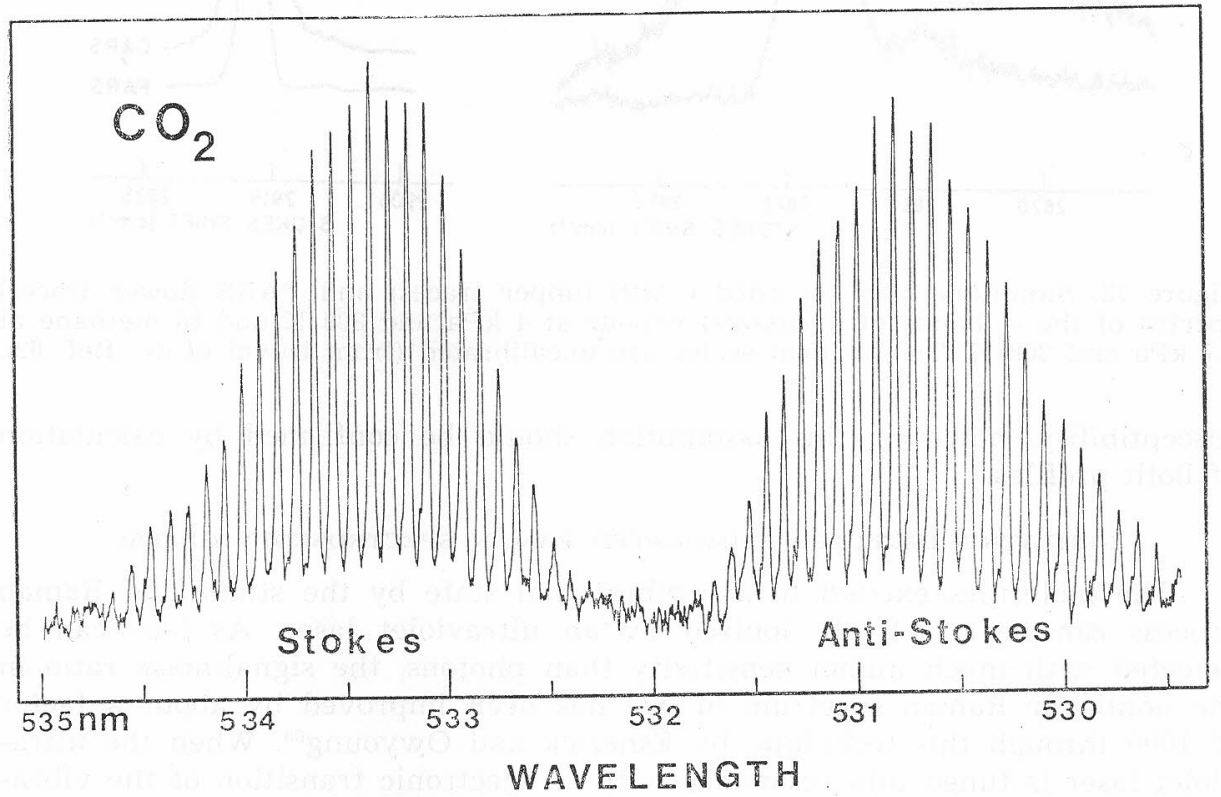

Figure 12. Rotational PARS spectrum of carbon dioxide at a pressure of $80 \mathrm{kPa}$ (from Barrett, Ref. 61).

In another medium resolution experiment a direct comparison between PARS and CARS spectra excited under similar conditions has been made ${ }^{6 *}$. Figure 13 shows the spectra of the $\nu_{1}$ bands of glyoxal and of methane at pressures of $4 \mathrm{kPa}$ and $6.7 \mathrm{kPa}$, respectively. The broader appearance of the CARS profiles may be due to the contribution of the real part of the nonlinear 


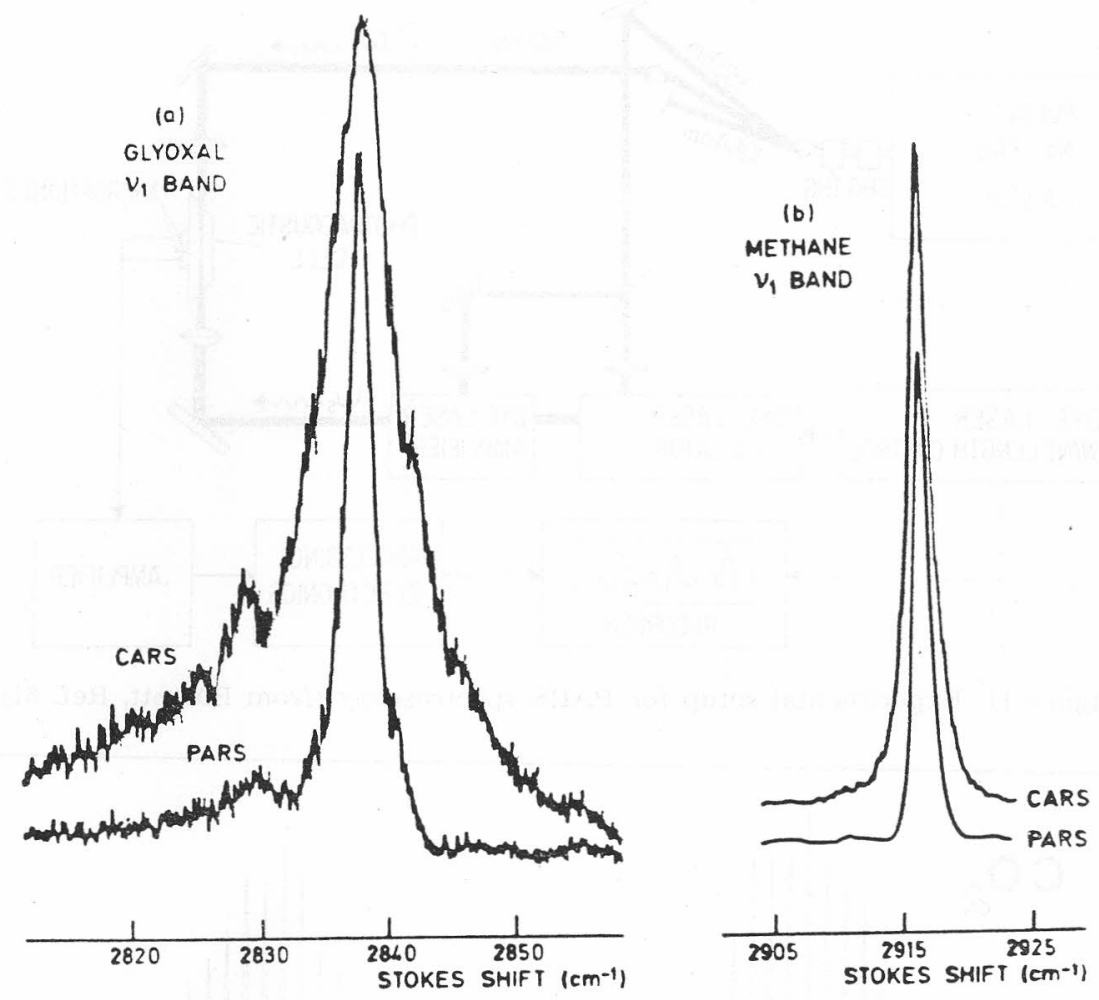

Figure 13. Simultaneously recorded CARS (upper traces) and PARS (lower traces) spectra of the $v_{1}$ bands of a) glyoxal vapour at $4 \mathrm{kPa}$ and $308 \mathrm{~K}$ and b) methane at $6.7 \mathrm{kPa}$ and $308 \mathrm{~K}$. The vertical scales are uncalibrated (from Duval et al., Ref. 62).

susceptibility, however, this assumption should be confirmed by calculation of both profiles.

\section{IONIZATION-DETECTED STIMULATED RAMAN SPECTROSCOPY (IDSRS)}

The molecules excited to a rovibrational state by the stimulated Raman process can be selectively ionized by an ultraviolet laser. As ions can be detected with much higher sensitivity than photons, the signal/noise ratio in the nonlinear Raman spectrum of NO has been improved by about a factor of 1000 through this technique by Esherick and Owyoung ${ }^{63}$. When the ultraviolet laser is tuned into resonance with an electronic transition of the vibrationally excited molecule, the ionization occurs in a two-photon resonant absorption process.

Figure 14 shows the experimental arrangement that has been used to resolve the degenerate Fermi doublet $\nu_{16}$ and $\nu_{2}+\nu_{18}$ of benzene $\mathrm{C}_{6} \mathrm{H}_{6}$ in a molecular beam experiment ${ }^{64}$. The two Fermi sub-bands could be recorded separately by selectively tuning the UV laser into resonance with electronic transitions from one of the two states as shown in Figure 15. When the Stokes laser is tuned, the rovibrational structure of only one Raman transition is 


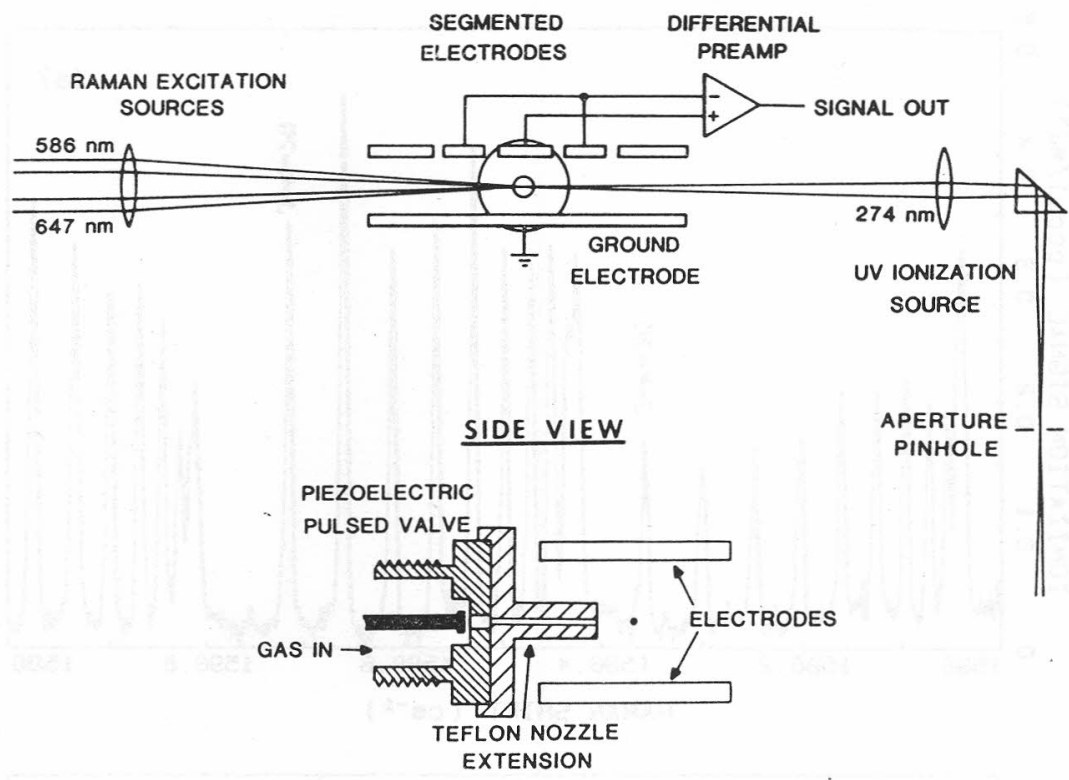

Figure 14. Experimental setup for ionization detected stimulated Raman spectroscopy in a pulsed molecular jet (from Esherick et al., Ref. 64).

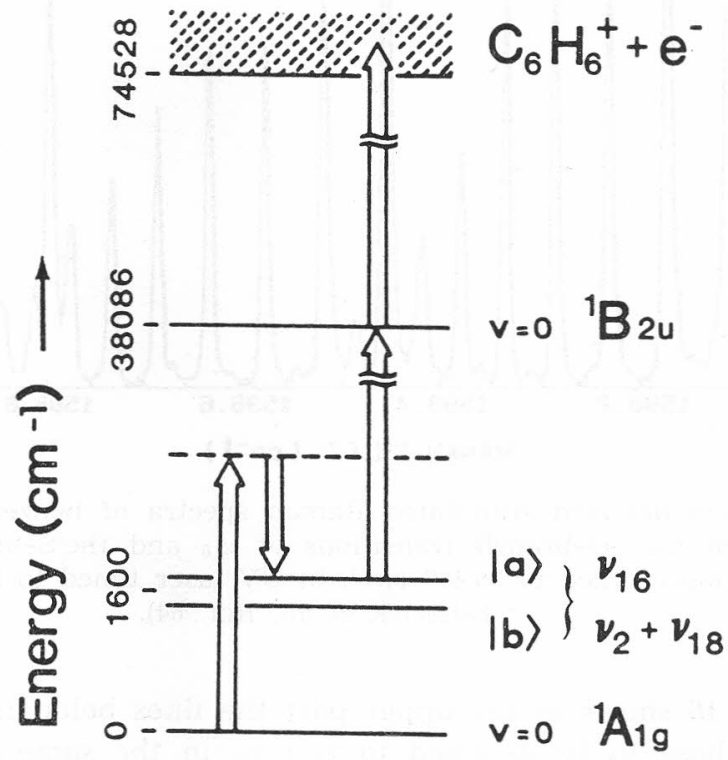

Figure 15. Energy level diagram illustrating the excitation scheme used by IDSRS (from Esherick et al., Ref. 64). 

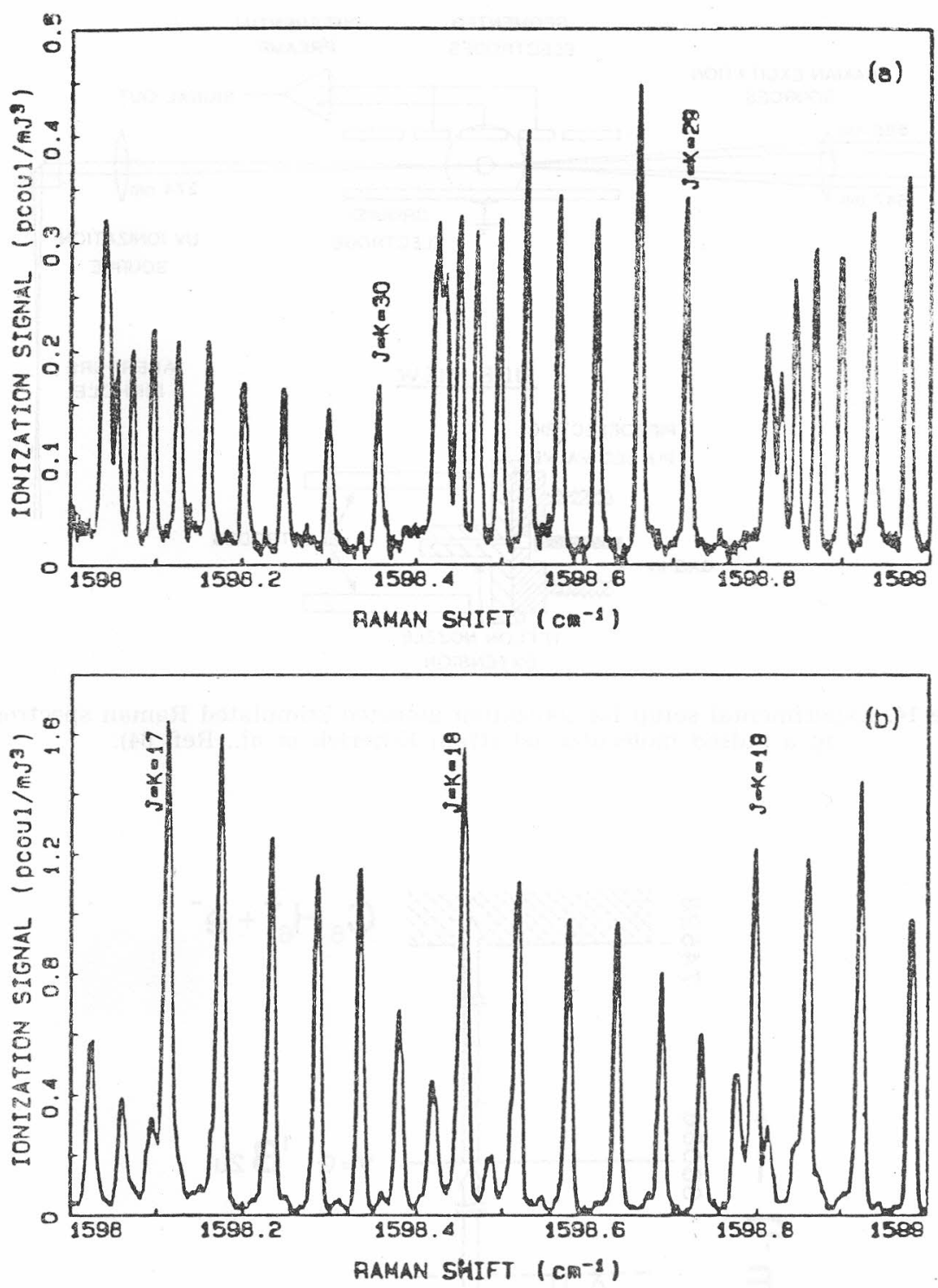

Figure 16. Ionization detected stimulated Raman spectra of benzene in the region of overlap between the ${ }^{\circ} \mathrm{O}$-branch transitions of $\nu_{16}$ and the ${ }^{s} \mathrm{~S}$-branch transitions of $\nu_{2}+\nu_{18}$. a) UV laser tuned to $364.67 \mathrm{~cm}^{-1}$, b) UV laser tuned to $36496 \mathrm{~cm}^{-1}$ (from Esherick et al., Ref. 64).

recorded. Figure 16 shows in the upper part the lines belonging to $\nu_{16}$ and in the lower part those to be assigned to $\nu_{2}+\nu_{18}$ in the same spectral region. An extensive analysis of the deconvoluted spectra $a^{65}$ yielded deperturbed spectroscopic constants for the interacting states which reproduce the line positions 
with a standard deviation of $0.0013 \mathrm{~cm}^{-1}$, which is comparable in accuracy with the results of modern infrared spectroscopic investigations.

Acknowledgement. - We thank all collaborators for their contribution to our work which was supported by the Deutsche Forschungsgemeinschaft and the Centre National de la Recherche Scientifique.

\section{REFERENCES}

1. G. Eckhardt, R. W. Hellwarth, F. J. Mc Clung, S. E. Schwartz, D. Weiner, and E. J. Woodbury, Phys. Rev. Lett. 9 (1962) 455.

2. N. Bloem berge n, Am. J. Phys. 35 (1967) 989.

3. W. J. Jones and B. P. Stoicheff, Phys. Rev. Lett. 13 (1964)) 657.

4. P. D. Maker and R. W. Terhune, Phys. Rev. 137 (1965) A801.

5. F. P. Schäfer (Ed.), Dye Lasers, Topics Appl. Phys. Vol. 1, 2nd ed., Berlin, Springer, 1977.

6. N. B lo e mberge n, Nonlinear Optics, New York, Benjamin, 1965.

7. J. W. Nible r and G. V. Knighte n, Coherent Anti-Stokes Raman Spectroscopy, in A. We ber (Ed.), Raman Spectroscopy of Gases and Liquids, Topics in Current Physics, Vol. 11, Berlin, Springer 1979, p. 253-299.

8. N. Bloembergen, H. Lotem, and R. T. Lynch, Jr., Indian J. Pure Appl. Phys. 16 (1978) 151.

9. G. L. Eesiey, Coherent Raman Spectroscopy, Oxford, Pergamon, 1981.

10. Y. Prior, IEEE J. Quantum Electr. QE-20 (1984) 37.

11. J. W. Nible r and G. A. P u b a $\mathrm{z}$, Coherent Raman Spectroscopy of Gases, in R. J. H. Clark and R. E. H ester (Eds.), Advances in Spectroscopy, Vol. 15, Chichester, Wiley, 1988, p. 1-50.

12. A. B. Harvey (Ed.), Chemical Applications of Nonlinear Raman Spectroscopy, New York, Academic Press, 1981.

13. W. Ki e f e r and D. A. Long (Eds.), Non-Linear Raman Spectroscopy and Its Chemical Applications, Dordrecht, Reidel, 1982.

14. P. Esherick and A. O w y u ng, High Resolution Stimulated Raman Spectroscopy, in R. J. H. C $1 \mathrm{ark}$ and R. E. H e ste $\mathrm{r}$ (Eds.), Advances in Infrared and Raman Spectroscopy, Vol. 9, London, Heyden-Wiley, 1982, p. 130-187.

15. H. W. Schrötter, H. Frunder, H. Berger, J. P. Boquillon, B. Lavorel, and G. Millot, High Resolution CARS and Inverse Raman Spectroscopy, in R. J. H. Clark and R. E. Hester (Eds.), Advances in Spectroscopy, Vol. 15, Chichester, Wiley, 1988, p. 97-147.

16. H. Görner, M. M a i er, and W. Ka is e r, J. Raman Spectrosc. 2 (1974) 363.

17. A. O w young, Opt. Commun. 22 (1977) 323.

18. A. O w young and E. D. Jones, Opt. Lett. 1 (1977) 152.

19. A. Owyoung, C. W. Patterson, and R. S. Mc Dowe11, Chem. Phys. Lett. 59 (1978) 156; 61 (1979) 636.

20. A. O w young, High Resolution Coherent Raman Spectroscopy of Gases, in: K. W. Rothe and H. W a l the r (Eds.), Laser Spectroscopy IV, Springer Ser. Opt. Sci. 21 (1979) 175.

21. R. Chaux, C. Milan, G. Millot, B. Lavorel, and R. Saint-Loup, J. Optics (Paris) 19 (1988) 3.

22. R. S. M c D ow e 11, C. W. Patterson, and A. O w young, J. Chem. Phys. 72 (1980) 1071.

23. P. Esherick, A. Owyoung, and C. W. Patterson, J. Phys. Chem. 87 (1983) 602.

24. J. E. Lolck, A. Owyoung, and P. Esherick, J. Raman Spectrosc. 16 (1985) 163.

25. G. Millot, B. Lavorel, R. Chaux, R. Saint-Loup, G. Pierre, H. Berger, J. I. Ste infeld, and B. Foy, J. Mol. Spectrosc. 127 (1988) 156.

26. A. Owyoung, P. Esherick, A. G. Robiette, and R. S. McDowell, J. Mol. Spectrosc. 86 (1981) 209.

27. B. Lavorel, R. Saint-Loup, G. Pierre, and H. Berger, J. Physique Letters 45 (1984) L295.

28. S. Q. MI o, R. Saint-Loup, A. Aboumajd, P. Lepage, H. Berger, and A. G. Robiette, J. Raman Spectrosc. 13 (1982) 257. 
29. B. Lavorel, P. Lepage, R. Saint-Loup, and H. Berger, unpublished work.

30. P. Esherick, A. Owyoung, and C. W. Patterson, J. Mol. Spectrosc. 86 (1981) 250.

31. P. Esherick and A. Owyoung, J. Mol. Spectrosc. 92 (1982) 162.

32. H. Frunder, D. Illig, H. Finsterhölzl, H. W. Schrötter, B. Lavorel, G. Roussel, J. C. Hilico, J. P. Champion, G. Pierre, G. Poussigue, and E. Pascaud, Chem. Phys. Lett. 100 (1983) 110.

33. M. Terki-Hassaine, Thèse 3ème Cycle, Université de Bourgogne, Dijon 1987.

34. J. J. Valentini, P. Esherick, and A. Owyoung, Chem. Phys. Lett. 75 (1980) 590.

35. J. Pliva, M. Terki-Hassaine, B. Lavorel, R. Saint-Loup, J. S a ntos, H. W. Schrötter, and H. Berger, to be published.

36. D. A. Gree $\mathrm{nh}$ alg h, Quantitative CARS Spectroscopy, in: R. J. H. Clark and R. E. H e ster (Eds.), Advances in Spectroscopy, Vol. 15, Chichester, Wiley, 1988 , p. $193-251$.

37. B. Lavorel, G. Millot, R. Saint-Loup, C. Wenger, H. Berger, J. P. Sala, J. Bonamy, and D. Robert, J. Physique 47 (1986) 417.

38. L. A. Rahn and R. E. Palmer, J. Opt. Soc. Am. B3 (1986) 1164.

39. B. Lavorel, G. Millot, J. Bonamy, and D. Robert, Chem. Phys. 115 (1987) 69.

40. D. A. Greenhalgh, F. IM. Porter, and S. A. Barton, J. Quant. Spectrosc. Radiat. Transfer 34 (1985) 95.

41. M. L. Koszykowski, L. A. Rahn, R. E. Palmer, and M. E. Coltrin, J. Phys. Chem. 91 (1987) 41.

42. B. Lavorel, R. Chaux, R. Sa int-Loup, and H. Berger, Opt. Commun. 62 (1987) 25.

43. J. J. B arrett and R. F. Begle y, Appl. Phys. Lett. 27 (1975) 129.

44. A. Hirth and K. Vollrath, Opt. Commun. 18 (1976) 213.

45. V. I. Fabelinsky, B. B. Krynetsky, L. A. Kulevsky, V. A. Mishin, A. M. Prokhorov, A. D. Savel'ev, and V. V. Smirnov, Opt. Commun. 20 (1977) 389.

46. H. Frunder, L. Matziol, H. Finsterhölzl, A. Beckmann, and H. W. Schrötter, J. Raman Spectrosc. 17 (1986) 143.

47. H. Frunder, R. Angstl, D. Illig, H. W. Schrötter, L. Lechuga- Fossat, J. M. Flaud, C. Camy-Peyret, and W. F. Murphy, Can. J. Phys. 63 (1985) 1189.

48. R. Angst1, H. Finsterhölzl, H. Frunder, D. Illig, D. Papoušek, P. Pracna, K. Narahari Rao, H. W. Schrötter, and S. Urb a n, J. Mol. Spectrosc. 114 (1985) 454.

49. H. W. Schrötter and B. Lavorel, Pure Appl. Chem. 59 (1987) 1301.

50. J. E. Lolck, Chem. Phys. Lett. 106 (1984) 143.

51. J. P. Boquillon, Y. Ouazzany, and R. Chaux, J. Appl. Phys. 62 (1987) 23.

52. Y. Ouazzany, J. P. Boquillon, and B. Lavorel, Can. J. Phys. 65 (1987) 1588.

53. Y. O uazzany and J. P. Boquillon, Europhysics Lett. 4 (1987) 421.

54. Y. Ouazzany, J. P. Boquillon, and H. W. Schrötter, Mol. Phys. 63 (1988).

55. A. S. Pine and G. Gualachvili, J. Mol. Spectrosc. 79 (1980) 84.

56. L. S. Rothman and L. D. G. Young, J. Quant. Spectrosc. Radiat. Transfer 25 (1981) 502.

57. L. Ros enmann, private communication.

58. D. Robert and J. Bon a my, J. Physique 40 (1979) 923.

59. L. Rosenmann, J. M. Hartmann, M. Y. Perrin, and J. Taine, J. Chem. Phys. 88 (1988) 2999.

60. J. J. Barrett and M. J. Berry, Appl. Phys. Lett. 34 (1979) 144.

61. J. J. Barrett, Photoacoustic Raman Spectroscopy in Gases, in Ref. 12, p. $89-169$. 
62. A. B. Duva 1, D. A. King, R. Ha ines, N. R. Is e nor, and B. J. Orr, J. Raman Spectrosc. 17 (1986) 177.

63. P. Esherick and A. O w y oung, Chem. Phys. Lett. 103 (1983) 235.

64. P. Esherick, A. O w young, and J. Pliva, J. Chem. Phys. 83 (1985) 3311.

65. J. Pliva, P. Esherick, and A. O w y o n g, J. Mol. Spectrosc. 125 (1987) 393.

66. H. Berger, B. Lavovel, G. Millot, R. Saint-Loup, and R. $\mathrm{Chaux}$, in R. J. H. Clark and D. A. Long (Eds.), Proc. XIth Int. Conf. Raman Spectrosc., Chichester, Wiley, 1988, pp. 157-158.

\title{
SAZ̆ETAK
}

\section{Nelinearna Ramanova spektroskopija visokog razlučivanja u plinovima}

\author{
H. W. Schrötter, H. Berger, I. P. Boquillon, B. Lavorel i G. Millot
}

Primjenljivost Ramanove spektroskopije na istraživanje plinova uvelike je poboljšana razvojem različitih metoda nelinearnog Ramanova raspršenja. Kada se dva laserska snopa, od kojih je jedan promjenljive frekvencije fokusiraju na uzorku, dolazi do stimuliranog Ramanova procesa čim je razlika frekvencija dvaju lasera jednaka Raman-aktivnoj rovibracijskoj ili rotacijskoj frekvenciji prijelaza u uzorku, a odgovarajuće stanje je napučeno iznad prosjeka. Ramanova rezonancija može se detektirati na različite načine: koherentnim anti-Stokesovim Ramanovim raspršenjem (CARS), pojačanjem u jednom od snopova (stimulirana Ramanova spektroskopija pojačanja, SRGS) ili slabljenjem u drugom (inverzna Ramanova spektroskopija, IRS), ili čak detekcijom fotoakustičkog signala (fotoakustička Ramanova spektroskopija, PARS). Selektivna ionizacija pobuđenih molekula trećim, ultraljubičastim laserskim pulsom (ionizacijski detektirano stimulirano Ramanovo raspršenje, IDSRS) znatno pojačava osjetljivost u posebnim slučajevima.

Instrumentalno razlučivanje tih tehnika određeno je konvolviranim širinama linija lasera upotrebljenih za pobudu. To je posebno važno za istraživanje rotacijsko-vibracijskih spektara visokog razlučivanja u plinovima. 